\title{
South African performance and archives of memory
}

YVETTE HUTCHISON

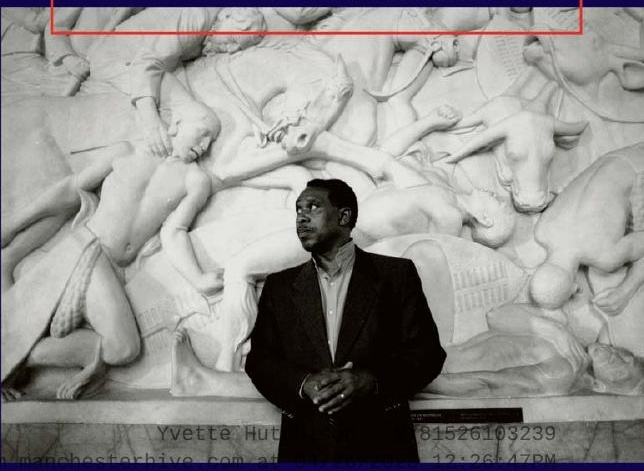


South African performance and archives of memory

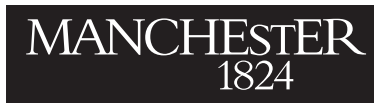

Manchester University Press 


\title{
theatre \\ theory - practice \\ - performance -
}

\author{
series editors \\ MARIA M. DELGADO \\ MAGGIE B. GALE \\ PETER LICHTENFELS \\ advisory board \\ MICHAEL BILLINGTON \\ SANDRA HEBRON \\ MARK RAVENHILL \\ JANELLE REINELT \\ PETER SELLARS \\ JOANNE TOMPKINS
}

This series will offer a space for those people who practise theatre to have a dialogue with those who think and write about it.

The series has a flexible format that refocuses the analysis and documentation of performance. It provides, presents and represents material which is written by those who make or create performance history, and offers access to theatre documents, different methodologies and approaches to the art of making theatre.

The books in the series are aimed at students, scholars, practitioners and theatre-visiting readers. They encourage reassessments of periods, companies and figures in twentiethcentury and twenty-first-century theatre history, and provoke and take up discussions of cultural strategies and legacies that recognise the heterogeneity of performance studies. The series editors, with the advisory board, aim to publish innovative challenging and exploratory texts from practitioners, theorists and critics.

also available

The Paris Jigsaw: Internationalism and the city's stages

DAVID BRADBY AND MARIA M. DELGADO (EDS)

Theatre in crisis? Performance manifestos for a new century MARIA M. DELGADO AND CARIDAD SVICH (EDS)

World stages, local audiences: Essays on performance, place, and politics PETER DICKINSON

Performing presence: Between the live and the simulated GABRIELLA GIANNACHI AND NICK KAYE

Performance in a time of terror: Critical mimesis and the age of uncertainty JENNY HUGHES

Jean Genet and the politics of theatre: Spaces of revolution CARL LAVERY

Not magic but work: An ethnographic account of a rehearsal process GAY MCAULEY

'Love me or kill me': Sarah Kane and the theatre of extremes GRAHAM SAUNDERS

Trans-global readings: Crossing theatrical boundaries CARIDAD SVICH

Negotiating cultures: Eugenio Barba and the intercultural debate IAN WATSON (ED.) 


\section{South African}

\section{performance and archives of memory}

YVETTE HUTCHISON

Manchester University Press

Manchester and New York

distributed in the United States exclusively by Palgrave Macmillan 
Copyright (c) Yvette Hutchison 2013

The right of Yvette Hutchison to be identified as the author of this work has been asserted by her in accordance with the Copyright, Designs and Patents Act 1988.

Published by Manchester University Press

Oxford Road, Manchester M13 9NR, UK

and Room 400, 175 Fifth Avenue, New York, NY 10010, USA

www.manchesteruniversitypress.co.uk

Distributed in the United States exclusively by

Palgrave Macmillan, 175 Fifth Avenue, New York,

NY 10010, USA

Distributed in Canada exclusively by

UBC Press, University of British Columbia, 2029 West Mall,

Vancouver, BC, Canada V6T 1Z2

British Library Cataloguing-in-Publication Data

A catalogue record for this book is available from the British Library

Library of Congress Cataloging-in-Publication Data applied for

ISBN 9780719083730 hardback

First published 2013

The publisher has no responsibility for the persistence or accuracy of URLs for any external or third-party internet websites referred to in this book, and does not guarantee that any content on such websites is, or will remain, accurate or appropriate.

Typeset by Servis Filmsetting Ltd, Stockport, Cheshire 